\title{
GANGGUAN EMOSI PADA TOKOH UTAMA CERPEN PULANG KARYA BEJO (Suatu Kajian Psikologi Sastra)
}

\author{
Tio R J Nadeak \\ Institut Agama Kristen Negeri Tarutung \\ Email: tiorjnadeak@yahoo.co.id
}

\begin{abstract}
ABSTRAK
Abstrak-Penelitian ini bertujuan untuk menginterpretasikan gangguan emosi tokoh utama yang digambarkan dalam cerpen yang berjudul Pulang. Sesuai dengan latar belakang yang sudah dipaparkan di atas maka ini bertujuan untuk memperoleh pemahaman tentang jenis gangguan emosi yang digambarkan oleh pengarang dalam cerpen Pulang. Penelitian ini menggunakan metode analisis deskriptif. Analisis terhadap cerpen Pulang merupakan penelitian kualitatif. Teknik pengambilan data adalah dengan cara memberi tanda teks terhadap kalimat ataupun pernyataan yang sesuai dengan permasalahan.teks yang diberi tanda adalah teks yang relevan dengan permasalahan yang ada dalam penelitian ini. Teknik yang digunakan adalah teknik pustaka: membaca, menyeleksi data.
\end{abstract}

Kata kunci: analisis, gangguan emosi

\section{PENDAhuluan}

Sastra merupakan sebuah tiruan dari kenyataan, karena persoalan yang dihadirkan tidak pernah lepas dari kehidupan nyata walaupun dalam bentuk, fiksi seperti cerpen, novel, drama dan lainnya. Menurut Wellek dan Warren (1989) sastra adalah segala sesuatu yang tertulis, demikian juga selain sastra yang berbentuk tulisan, juga berupa cetakan, untuk membedakan yang mana sastra dan bukan sastra dapat dilihat dari beberapa ciri yaitu 1) sastra imajinatif (fictionality), 2) sastra mempunyai nilai seni estetika (valuaes), 3) sastra memiliki bahan yang khas (special us of language). Sastra juga merupakan hasil karya manusia yang dituangkan dalam medium bahasa dan diekspresikan melalui tulisan sehingga dapat dinikmati pembaca.

Pada dasarnya isi sebuah karya sastra dapat memuat perilaku manusia melalui karakter dalam tokoh-tokoh cerita. Beragam perilaku manusia dapat dituangkan dalam bentuk cerita. Kadangkadang jika diamati secara cermat sering terjadi perulangan. Pola atau keterulangan inilah yang ditangkap sebagai fenomena dan seterusnya diklasifikasikan ke dalam kategori tertentu seperti gejala kejiwaan, sosial, dan masyarakat. Sebagaimana misalnya perilaku yang berhubungan gangguan emosi, pemahaman mengenai gangguan emosi dalam novel ini dapat dilakukan dengan mengadakan pendekatan psikologi terhadap karya sastra. Emosi sebagai suatu kondisi yang berdasar pengalaman, tindakan dan perubahan psikologis seperti yang terjadi dalam ketakutan, kegelisahan atau kesenangan.

Seseorang disebut mengalami gangguan emosi, jika keadaan emosi dalam dirinya mengalami gangguan. Seperti karena emosi yang dialami terlalu kuat (misalnya sangat sedih), tidak ada emosi pada dirinya (misalnya tidak merasa bahagia) atau emosinya justru menimbulkan konflik pada dirinya 
(misalnya terlalu sering marah). Karena itulah emosi merupakan keadaan penting yang dimiliki manusia dalam kehidupan sehari-hari.

Cerpen sebagai salah satu karya sastra merupakan tiruan dari kenyataan yang dapat memuat realitas psikologis seperti gangguan kejiwaan, karakter yang menyimpang dari tokohnya. Menurut Iswanto, " karya sastra lahir di tengahtengah masyarakat sebagai hasil imajinasi pengarang serta refleksinya terhadap gejala-gejala sosial di sekitarnya'.

Psikologi sastra adalah kajian sastra yang memandang karya sebagai aktivitas kejiwaann (Endraswara 2011: 96). Dalam kenyataannya sebuah karya sastra hampir tidak lepas dari fakta psikologis tentang konflik batin, kedamaian, kebencian, atau keindahan, yang semuanya menyangkut persoalan kehidupan yang telah dirangkai dalam kreatifitas imajiner. Psikologi sastra dengan demikian adalah sastra menyususn sebuah fakta psikologis yang dimodifikasi dari model-model realitas ke dalam susunan naratif yang ditentukan oleh selera, kreatifitas, gaya tertentu dari pangarang atau sebuah fakta imajiner yang kesemuanya semata-mata lahir dari dimensi kognitif, emosi, spritualitas, kebermaknaan yang menimbulkan konflik psikologis pada pembacanya.

Tujuan penulisan ini untuk menginterpretasikan gangguan emossi tokoh utama yang digambaran dalam cerpen yang berudul Pulang. Sesuai dengan latar belakang yang sudah dipaparkan di atas maka ini bertujuan untuk memperoleh pemahaman tentang jenis gangguan emosi yang digambarkan oleh pengarang dalam cerpen Pulang, memperoleh latar belakang timbulnya gangguan emosi tokoh.

\section{KAJIAN PUSTAKA \\ 1. Gangguan Emosi}

Emosi adalah suatu pengalamn yang sadar memengaruhi kegiatan jasmani dan afektif yang mengikuti keadaan keadaankeadaan fisiologis dan mental yang muncul dan penyusunan batiniah dan yang mengekspresikan dirinya dalam tingkah laku yang tampak. (Baharuddin 2009: 55). Emosi dapat digolongkan menjadi emosi yang menyenangkan dan emosi yang tidak menyenangkan dann dapat puls digolongkan berdasar intensitasnya. Emosi untuk keadaan yang emiliki intensitas tinggi dan perasaan untuk keadaan yangg memiliki intensitas rendah. Emosi yang lebih kuat seperti takut atau marah. Suasana emosi negatif seperti defresi, stres dan kecemasan dapat mengganggu dan menurunkan daya ingat. Dari pendapat tersebut dapat disimpulkan bahwa seseorang disebut mengalami gangguan emosi, jika ia mengalami keadaan emosi yang menimbulkan gangguan yang mewarnai kehidupannya, terkadang karena berbagai sebab banyak orang yang pada akhirnya mengalami gangguan emosi disebabkan karena tidak dapat mengontrol emosinya agar tetap stabil.

Pada umumnya apa yang dilakukan manusia sehari-hari disertai oleh berbagai perasaan baik perasaan senang maupun tidak senang dengan intensitas lemah, sedang atupun kuat. Dalam kehidupan manusia baik sebagai individu maupun sosial akan menimbulkan beragam emosi, dan kenyataannya bahwa semua manusia pasti mengalami berbagai macam peristiwa yang melibatkan emosi. Beberapa kriteria emosi normal, yaitu: (1) emosi dapat diramalkan dan cocok, yakni emosi berguna, diharapkan, dan relevan dengan situasi stimulus; (2) emosi tidak seharusnya berlangsung lama atau berhenti dengan mendadak, mengingat sifat dan pentingnya keadaan yang menimbulkan reaksi emosional; (3) emosi yang diungkapkan 
tidak terlalu kuat dalam hubungannya dengan situasi. Yustinus mengatakan bahwa pola-pola emosi yang tidak normal antara lain afek yang tidak tepat, afek yang terlalu kaku, ambivalensi, kecemasan, apati, depersonalisasi, depresi, kegembiraan, ketidakstabilasn emosi, perasaan bersalah yang tidak rasional, mudah tersinggung.

Keadaan emosi dapat menimbulkan energi, tetapi dapat pula mengganggu, tergantung pada pengalaman orang yang mengalaminya. Rangsangan emosi yang ringan cenderung menghasilkan situasi yang baik. Tetapi jika emosi menjadikuat, baik menyenangkan atau tidak menyenangkan, biasanya menghasilkan gangguan perilaku.

Dari emosi bermacam-macam, seperti keadaan bergejolak, gangguan keseimbangan atau rspon kuat tak beraturan terhadap stimulus. Ada satu hal yang sama yaitu bahwa setiap defenisi tersebut keadaan emosional itu menunjukkan penyimpangan dari keadaan normal. Keadaan yang normal adalah keadaan yang tenang stsu keadaan seimbang fisik dan sosial.

Gangguan emosi adalah jenis gangguan yang sifatnya ringan, tetapi apabila dibiarkan terus menerus bisa menjadi berat berpa gangguan mental sedangkan gangguan mental adalah penyakit jiwa, yang menyebabkan penderita tidak sanggup menilai dengan baik kenyataan, tidak dapat lagi menguasai dirinya. Jadi dapat dikatakan bahwa gangguan emosi berbeda dengan gangguan mental tetapi dapat menjadi gejala awal dari timbulnya gangguan mental. Gangguan emosi dapat dikategorikan ringan sampai berat. Menurut Lake ada beberapa jenis gangguan emosi. a. Krisis jangka pendek yang mungkin bisa berbahaya karena sering diabaikan oleh penderitannya.

b. Gangguan jangka panjang, yakni munculya rasa tidak bahagia yang tak tertangguhkan karena alasan yang jelas.

Menurutnya salah satu cara melihat apakah seseorang mengalami gangguan emosi adalah apabila ia selalu merasa tidak bahagia.

Menurut Yustinus penyakit mental adalah gangguan atau penyakit yang menghalangi seseorang hidup sehat seperti yang diinginkan baik oleh diri sendiri maupun oleh orang lain. Jumlah gangguan mental yang dapat diidentifikasi tidak terbatas, mulai dari kesulitan emosional tingkat sampai gangguan mental yang berat. Diantara gangguan emosi yang dapat terjadi adalah:

a. Afek yang tidak tepat yaitu gangguan emosi di mana ada ketidakcocokan antara sifat dari emosi yang diungkap dan situasi yang menyebabkannya.

b. Afek yang terlalu kaku adalah tetap mempertahankan suasana hati tertentu meskipun ada respon yang berbeda.

c. Ambivalensi adalah perasaan bertentangan yang timbul bersamaan.

d. Kecemasan adalah keadaan tegang, ketakutan, kekhawatiran, perasaan bersalah, perasaan tidak aman, dan kebutuhan akan kepastian.

e. Apati merupakan penumpulan emosi atau sikap tidak terpengaruh dalam bentuk masa bodoh.

f. Depersonalisasi adalah timbul peasaan tentang sesuatu yang tidak ada dan tidak adanaya keyakinan tentang identitas diri sendiri.

g. Depresi adalah suasana hati yang bercirikan perasaan sedih dan murung. 
h. Kegembiraan (elation) adalah bentuk kegembiraan yang ekstrem dan tidak tepat.

i. Ketidakstabilan emosi adalah ketidakstabilan yang ekstem dan respon emosi yang berubah-ubah.

j. Perasaan bersalah yang tidak rasional adalah respon emosi di mana orang mengatakan dirinya pantas dicela.

k. Mudah tersinggung cenderung memiliki respon yang berlebihan terhadap situasi yang bermacammacam dan perasan marah atau tidak sabar.

Dari pendapat tersebut dapat dikatakan bahwa gangguan emosi merupakan bagian dari gangguan mental dan bahwa gangguan emosi adalah sauatu keadaan yang berbeda dari keadaan emosi seseorang pada umumnya. Pendapat lainnya mengenai gangguan emosi diuraikan menurut Baihaqi diantaranya:
a. Anhedonia, yaitu ketidakmampuan merasakan kesenangan.
b. Kesepian yaitu merasa tidak ada orang yang menyayangi
c. Kedangkalan, yaitu emosinya datar, tumpul dan dingin.
d. Emosi yang tidak wajar, reaksi kesenangan/kesedihan yang tidak wajar
e. Emosi labil, emosi berubah secara cepat
f. Variasi afek dan emosi sepanjang hari, perubahan emosi sejak pagi sampai malam hari.
g. Afek yang terlalu kaku, mempertahankan terus suatu keadaan meskipun ada respon yang berlainan
h. Ambivalensi, yaitu ketidaktepatan perasaan pada benda.

i. Apati, yaitu perasaan tidak peduli

j. Amarah, permusuhan dalam bentuk agresi

k. Depresi, merasa sedih, susah, merasa tak berguna

1. Kecemasan, kwatir dan gugup Berdasarkan uraian di atas yang dimaksud gangguan emosi adalah keadaan seseorang yang menunjukkan penyimpangan dari keadaan norma, seperti perubahan emosi secara cepat yang tidak terkendali hingga disertai tindakan agresi. Respon terhadap suatu kejadian tak beraturan seperti merasa senang disaat orang bersedih atau sebaliknya. Dan dapat disimpulkan bahwa ganguan emosi seperti: Afek yang tidak tepat, apati, depersonalisasi, deperesi, kecemasan, dan mudah tersinggung.

\section{Latar Belakang Gangguan Emosi}

Penyebab gangguan emosi menurut Albert Ellis, seorang psikologi klinis Amerika berpendapat bahwa penderitaan mental tidak langsung diakibatkan oleh masalah yang menimpa tetapi dari pendapat irasional dan keliru. Gangguan emosional datang tidak dari peristiwaperistiwa di dalam dunia nyata tetapi datang dari gagasan dan evaluasi yang tidak benar, terlalu menggeneralisasi dan irasional yang kita anut tentang peristiwaperistiwa itu.

Penyebab perilaku agresif dapat digolongkan dalam enam faktor sebagai berikut ini:

1. Faktor psikologis.

2. Faktor sosial

3. Faktor lingkungan

4. Faktor situasional

5. Faktor biologis

6. Faktor genetik

Penyebab gangguan emosi karena suatu peristiwa atau tindakan seseorang yang pernah mengalami peristiwa atau 
pengalaman yang tidak menyenangkan yang menimbulkan trauma seperti kematian atau kegagalan, jika peristiwa tersebut tidak dapat diterima seseorang sehingga perilakunya menjadi tidak terkendali . seperti gangguan emosi yang ringan hingga gangguan mental yang berat.

Beberapa faktor yang menjadi penyebab terjadinya gangguan mental antara lain:

1. Faktor fisiologis dan biologis, seperti terjadinya kerusakan pada otak.

2. Faktor psikologis, seperti rasa sepi, strees, kecemasan, dan sebagainya.

3. Faktor lingkungan seperti peperangan, kerusuhan rasial, kelaparan, kehidupan di penjara, lingkungan sekolah yang terlalu kompetitif.

Dari beberapa pendapat tersebut dapat disimpulkan bahwa gangguan emosi biasanya terjadi akibat suatu peristiwa yang menyedihkan, menakutkan atau mengganggu perasaan.

\section{Penyesuaian Diri}

Dalam kehidupan manusia senantiasa melakukan penyesuain diri supaya tetap terjadi keseimbangan dalam dirinya. Seseorang yang mengalami gangguan emosi, memiliki masalah dalam berhubungan dengan orang lain, seperti dengan teman dan tidak memiliki hubungan yang baik dengan orang dewasa di sekitarnya. Penyesuaian diri atau self adjusment menurut Daradjat adalah suatu proses dinamika yang bertujuan untuk mengubah tingkah laku agar terjadi hubungan yang selaras antara dirinya dan lingkungannya.

Menurut Daradjat penyesuaian diri memiliki dua jenis, yaitu penyesuaian diri pribadi dan penyesuaian diri sosial. penyesuaian diri pribadi adalah penyesuaian individu terhadap dirinya sendiri dan percaya diri sendiri. Sedangkan penyesuaian sosial merupakan suatu proses yang terjadi dalam lingkungan sosial tempat individu hidup dan berinteraksi dengannya. Sedangkan Kartono mengartikan penyesuaian diri sebagai usaha untuk mencapai keharmonisan pada diri sendiri dan pada lingkungan sehingga rasa bermusuhan, dengki, iri hati, prasangka, kecemasan, kemarahan sebagai respon pribadi yang tidak sesuai dengannya terkikis habis.

\section{METODE}

Analisis terhadap cerpen Pulang merupakan penelitian kualitatif. Yaitu penelitian yang mengutamakan ke dalam penghayatan terhadap interaksi antara konsep yang dikaji secara empiris. Penelitian ini menggunakan metode analisis deskriptif. Sumber data dalam penelitian ini adalah sebuah cerpen yang berjudul Pulang karya Bejo yang menggambarkan adanya gangguan emosi yang diungkapkan lewat pernyataan, baik dalam bentuk dialog,maupun narasi serta unsur lain dalam sastra.

Teknik pengambilan data adalah dengan cara memberi tanda teks terhadap kalimat ataupun pernyataan yang sesuai dengan permasalahan.teks yang diberi tanda adalah teks yang relevan dengan permasalahan yang ada dalam penelitian ini. Teknik yang digunakan adalah teknik pustaka:membaca, menyeleksi data. Dalam teknik analisis data ini, ada beberapa langkah yang ditempuh dalam menganalisis sastra yang berjudul Pulang yaitu:

1. Menganalisis adanya gangguan emosi seperti afek yang tidak tepat, depersonalisasi, defresi, kecemasan, mudah tersinggung dan apati dalam cerpen Pulang. 
2. Menganalisis gangguan emosi seperti afek yang tidak tepat, depersonalisasi, defresi, kecemasan, mudah tersinggung dan apati dalam cerpen Pulang.

3. Menyimpulkan gangguan emosi seperti afek yang tidak tepat, depersonalisasi, defresi, kecemasan, mudah tersinggung dan apati dalam cerpen Pulang.

\section{PEMBahasan}

Setelah menganalisis cerpen yang berjudul Pulang karya Bejo ditemukan beberapa gangguan emosi seperti afek yang tidak tepat, depersonalisasi, defresi, kecemasan, mudah tersinggung, apati. Gangguan emosi di atas akan dijabarkan sebagai berikut:

1. Afek yang tidak tepat.

Afek yang tidak tepat yaitu gangguan emosi di mana ada ketidakcocokan antara sifat dari emosi yang diungkap dan situasi yang menyebabkannya. Ini dapat dilihat pada kalimat:

Itulah awal anarki dalam dirinya. Anarki itu memuncak ketika beberapa minggu lalu seorang temannya yang akan pulang ke Indonesia mengatakan melalui telepon bahwa ia harus menceraikan istrinya dan mencari istri baru. Mas harus cerai dan cari istri baru," begitu kata temannya di sela-sela pembicaraan telepon mereka.

Maksudnya, si pelaku mengalami ganguan emosi yang kecil akibat telepon dari seorang temannya yang menyampaikan mimpi tersebut bahwa si pelaku harus menceraikan istrinya.

2. Depersonalisasi

Depersonalisasi adalah timbul peasaan tentang sesuatu yang tidak ada dan tidak adanya keyakinan tentang identitas diri sendiri. Ini dapat dilihat pada kalimat: a. Dari perjalanan pulang dari Narita pikirannya tidak menentu. Marah, iri dan lainnya begitu berkecamuk dalam benaknya. Iri karena temannya pulang ke negeri yang sangat dirindukan, temannya pulang dan bakal merasakan surga tanah airnya yang tak mengenal dingin, pulang dan bertemu denan orang-orang yang ramah, sedrhana dan baik-baik. Sementara ia harus tinggal di Tokyo dengan berjuta kebosanan.

b. Bagaimana mungkin $\mathrm{Yu}$ Ling tahu saya sedang Jiong, wong kita lama tidak bertemu,' tanyanya bukan untuk menegaskan pernyataan Ling yang telah dianggap kakaknya sendiri tetapi sekedar berbasa-basi.

3. Defresi

Defresi adalah suasana hati yang bercirikan perasaan sedih dan murung. Ini dapat dilihat pada kalimat berikut: Rasa sakit di dada dan kepalanya akibat kata cerai dan cari istri baru kembali berpusing, dan menyodok pembuluhpembuluh tipis otaknya. Untung saat itu Yamanote kosong sehingga ia bisa menemukan tempat duduk yang enak untuk menahan dentaman gejolak rasa itu.

4. Kecemasan

Kecemasan adalah keadaan tegang, ketakutan, kekhawatiran, perasaan bersalah, perasaan tidak aman, dan kebutuhan akan kepastian. Ini dapat dilihat pada kalimat:

a. Di mana saja ia berada saat berada di Yamanote-Sen, menjelang tidur, sarapan dan terutama saat berak sambil menghabiskan berbatangbatang rokok di WC.

b. Benaknya masih dipenuhi pikiran bagaimana harus menyampaikan beban yang dipikulnya selama ini. Haruskah aku mengatakan malam 
ini kepadanya, bagaimana aku akan mengatakan malam ini. Apakah pantas, istriku yang sudah ngantuk ku ajak bicara maslaah berat ini.

5. Mudah tersinggung

Mudah tersinggung cenderung memiliki respon yang berlebihan terhadap situasi yang bermacammacam dan perasan marah atau tidak sabar. Ini dapat dilihat pada kalimat berikut ini:

Meski begitu, ia masih memiliki waktu luang yang sangat banyak. Justru itulah masalahnya. Hingga menimbulkan kebosanannya. Awalnya ia bisa membujuk dirinya dengan berjala-jalan ke Ike atau tempat lain. Namun lama kelamaan dirinya tidak bisa dibohongi lagi dengan jalan-jalan atau sekedar menemui temantemannya. Ia perlu bekerja teratur, kali ini tidak hanya sekedar untuk aktualisasinya, bahkan lebih parah. Terkadang hanya untuk membeli rokok.

6. Apati, yaitu perasaan tidak peduli

Tokoh utama dalam cerpen juga mengalami gangguan emosi apati. Apati yaitu perasaan tidak peduli. Ini ditemukan pada kalimat-kalimat dalam cerpen:

Dua kucing yang bercanda di pelataran patung Saigo Takamori di Ueno terlonjak lari mencari persembunyian di rumput dekat makam Shogitai ketika pantat dua satwa itu terkena kaleng minuman bekas yang ditendangnya.

Perasaan tak peduli yang dimaksud pada kalimat di atas yaitu bahwa si pelaku utama tersebut tidak memikirkan dengan apa yang sudah dilakukkan terhadap kaleng minuman bekas yang ditendangnya, di mana akan mengganggu suasana di tempat tersebut.

\section{SINOPSIS}

Kata cerai dan mencari istri baru selalu menghantui. Ketika tidur,sarapan,dikamar mandi sambil menghabiskan berbatangbatang rokok kata-kata itu selalu ada dibenaknya yang dapat merusak ritme dan keseimbangan tubuhnya. Malam yang telah larut, dia yang sendirian tidak disadarinya. Dengan masalah yang dihadapi Ia ingin pulang tetapi begitu masuk gerbong Yamanote keraguannya untuk pulang kembali mencuat. Rasa sakit di dada dan kepalanya akibat kata cerai dan cari istri baru kembali berpusing dan menyodok pembuluh-pembuluh tipis otaknya tetapi Ia tetap pulang.

Memasuki Oosaki denyut dan jantung makin keras. Mendekati tujuannya pompa darah semakin kencang. Ia belum bisa memutuskan bagaimana menyelesaikan masalahnya dengan istrinya. Sebenarnya tidak ada masalah dalam perkawinan mereka selain sampai saat ini belum mempunyai anak. Istrinya ini adalah teman sewaktu mereka sekolah dulu. Tiba saatnya mereka hidup sendiri, masa itu jg tidak jadi malasah. Istrinya jug sabar dan tabah saat Ia menghabiskan malam yang seharusnya dilalui bersama istrinya tetapi harus melayani teman-temannya yang berdatangan hingga larut malam. Terkadang sampai subuh. Saat Ia kehilangan pekerjaan, istrinya menyarankan untuk menerima pekerjaan dari temannya tetapi ditolak karena gaji yang kecil. Akhirnya Ia meninggalkan pekerjaan yang tidak disukainya dan tinggal di Jakarta. Suatu hari istrinya memohon agar Ia menemaninya kembali ke Tokyo. Tokyo begitu asing baginya, selama di sana istrinya semacam tongkat penunjuk jalan baginya karena ia tidak mengenal 
budaya di Tokyo dan ia pun menunjukkan kebosanan. Itulah awal anarki dalam dirinya. Anarki itu memuncak ketika beberapa minggu lalu seorang temannya yangakan pulang e Indonnesiamengatakan melalui telepon bahwa Ia harus menceraikan istrinya dan mencari istri baru dengan alas an bahwa pernikahan mereka tidak ada barokahnya. Dalam perjalanan pulang pikirannya tak menentu, marah, iri begitu berkecamuk dalam benaknya.

\section{KESIMPULAN}

Pada dasarnya isi sebuah karya sastra dapat memuat perilaku manusia melalui karakter dalam tokoh-tokoh cerita. Beragam perilaku manusia dapat dituangkan dalam bentuk cerita. Kadangkadang jika diamati secara cermat sering terjadi perulangan. Pola atau keterulangan inilah yang ditangkap sebagai fenomena dan setrusnya diklasifikasikan ke dalam kategori tertentu seperti gejala kejiwaan, sosial, dan masyarakat.

Cerpen sebagai salah satu karya sastra merupakan tiruan dari kenyataan yang dapat memuat realitas psikologis seperti gangguan kejiwaan, karakter yang menyimpang dari tokohnya.

Gangguan emosi yang ditemukan dalam cerpen Pulang yaitu afek yang tidak tepat, depersonalisasi, defresi, kecemasan, mudah tersinggung dan apati. Cerpen yang berjudul Pulang ini secara keseluruhan menunjukkan karakter seseorang melalui emosi -emosi tokoh dan sebaiknya supaya lebih mudah dipahami oleh si pembaca sebaiknya menggunakan bahasa yang tidak sulit dipahami, penyampaian cerita yang kronologis juga akan membantu si pembaca untuk memahami sebuah cerita.

\section{DAFTAR PUSTAKA}

[1] Baharuddin, H. 2009. Pendidikan Psikologi Perkembangan. Jakarta: ArRuzz Media

[2] Endraswara, Suwardi. 2008. Metode Penelitian Psikologi Sastra. Yogyakarta: MedPress (Anggota IKAPI)

[3] Endraswara, Suwardi. 2011 Metodologi Penelitian Sastra. Epistemologi, Model, Teori, dan Aplikasi.Yogyakarta: CAPS

[4] http://klinikautisiindonesia.wordpress.c om/2012/11/04/gangguan-emosi-padaanak-gejala-dan-penanganannya/

[5] Wellek, Rene dan Austinn Warren. 1989. Teori Kesusasteraan. Terjemahan Melani Budianto. Jakarta: Gramedia 